\title{
Evaluation of Potency Spent Coffee Grounds for Make Black Compost
}

\author{
Asmak Afriliana ${ }^{1,2^{*}}$, Endar Hidayat $^{1}$, Mitoma Yoshiharu $^{1}$, Masuda Taizo $^{1}$, and Hiroyuki Harada ${ }^{1}$ \\ ${ }^{1}$ Environmental Sciences, Life and Environmental Department, 727-0022 Prefectural University of Hiroshima, Japan \\ ${ }^{2}$ Agricultural Technology, Agricultural Product Department, 68121 University of Jember, Indonesia
}

\begin{abstract}
The aim for this research is to make black compost from spent coffee grounds (SCG). The content of hemicellulose and lignin from SCG were $37.28 \%$ and $22.45 \%$. For mineral content, Potassium $(3 \mathrm{~g} / \mathrm{kg})$ is the most abundant element in spent coffee ground, followed by calcium $(1.23 \mathrm{~g} / \mathrm{kg})$, magnesium $(1.11 \mathrm{~g} / \mathrm{kg})$, phosphorus $(0.89 \mathrm{~g} / \mathrm{kg})$ and natrium $(0.7 \mathrm{~g} / \mathrm{kg})$. SCG also contains Carbon and Nitrogen ratios 1:19.5 which approaches the $\mathrm{C} / \mathrm{N}$ ratio of the soil 1: 20. Composting process in aerobic condition for 2 months using Fungi, Bacillus and Lactic Acid Bacteria activator, produce black compost with good characteristic for plant and soil, such as $\mathrm{C} / \mathrm{N}$ ratio under $1: 10$ and $\mathrm{pH}$ around 6 to 9 .
\end{abstract}

\section{Introduction}

Coffee is the most favorite beverage in the world. Global coffee production has increased $21 \%$ since 2005 with total production estimated at more than 8.5 million tons. During producing expresso, spent coffee grounds (SCG) produced are $550-670 \mathrm{~g} / \mathrm{kg}^{1}$. More than $90 \%$ of coffee production in developing countries ${ }^{2}$. Worldwide, spent coffee grounds production are around at 6 million tons per year ${ }^{3}$.

Composting technology has been widely applied to change organic matter into humus [1]. Compost is a biotransform process mediated by microorganisms with control to humidity, $\mathrm{pH}$, temperature, and carbon and nitrogen content ${ }^{5}$. Degradation that not complete will causing toxic for plant or called phytotoxicity [2,3]. Therefore, to make sure that the composting process is complete, it is necessary to analyze the physical, chemical and biological characteristics of compost [4].

The addition of activators in the composting process is one of the topics widely studied by scientists. Activator is added to enhance the composting process. Some activators commonly added include decomposer fungi, Bacillus strains, and Lactic Acid Bacteria. [5,6,7].

In this study were used activator fungi, Bacillus commercial, and Lactic Acid Bacteria. Bacillus is often found in compost at all stage [8]. These bacteria have capacity to produce spores and survive in various environmental condition better than other bacteria. They can produce extracellular polysaccharide hydrolyzing enzymes [9]. SCG consist of high cellulose and lignin, around $39 \%$ cellulose and $23 \%$ lignin [10]. This substrate can be degraded by fungi, because can produce cellulose enzyme. Fungi was used are local microorganism comes from isolated fertile soil in the mountain region, Japan. While, lactic acid bacteria due to their enzymatic and antagonistic properties they contributed to the efficient degradation of organic matter and, at the same time, inhibit the growth of other microorganisms, pathogenic for plants. In this study, we used yakult commercial as source of lactic acid bacteria.

Composting of SCG waste mixed with several ingredients such as cow dung and chicken manure to increase nutrition of microorganism, and balancing $\mathrm{C} / \mathrm{N}$ ratio. Therefore, the main objective of this study was to study the physical and chemical changes of the SCG mixture with cow dung and chicken manure at different concentrations and different activator.

\section{Material and Methods}

\subsection{Preparation Fungi Activator}

Fungi was isolated from field on Prefectural University of Hiroshima, then inoculated for 2 weeks in PDA (Potato Dextrose Agar) medium. Several loopful of fungi were took up and inoculated in $100 \mathrm{~g}$ dried malt extract then added $1000 \mathrm{ml}$ distilled water, autoclaved $121^{\circ} \mathrm{C}$, and 20 minutes. Then cooling around 10 minutes. Stirring using Mixer MG-600 100 rpm, 36 hours. Then incubated 2 weeks, $25^{\circ} \mathrm{C}$. That mix solution was used as the inoculum or fungi activator [11].

\subsection{Preparation Lactic Acid Bacteria Activator}

2 bottles $(100 \mathrm{ml})$ of yakult added and mixed with $100 \mathrm{ml}$ fish hydrolysate, $100 \mathrm{~g}$ glucose, $100 \mathrm{~g}$ milk, 2 pcs eggs, $1000 \mathrm{ml}$ distilled water, then fermentation 2 weeks in $30^{\circ} \mathrm{C}$. Fungi inoculum after 2 weeks incubation was able to use as LAB activator.

\subsection{Preparation of Bacillus Activator}

Bacillus activator that we used is commercial activator. The Activator is patented by the Bio food Industry Research Center, and the Industrial technology center, Fukuoka Prefectural. Produced by the non-profit organization Eco cycle Kyushu / Okinawa Japan.

\subsection{Composting Method}

The study was conducted at Prefectural University of Hiroshima, Shobara campus. Each compost was produced in 1-liter container with air circulation (aerobic condition). The materials used in this study were SCG, cow dung and chicken manure commercial. 12 different treatments where then established, and they consisted of each four different rates of SCG co-composted with cow

*Corresponding author: ho-harada@pu-hiroshima.ac.jp 
dung and chicken manure commercial (Yasaki co. japan). 1 sample only SCG and water as control. Description of sample as explain below:

Control : SCG (250 gr) + water until MC 60\%

A1 : SCG $250 \mathrm{~g}+$ sugar $40 \mathrm{~g}+$ bacillus commercial (dilution 100 times) adding to sample until Moisture Content $60 \%$

B1 : SCG $200 \mathrm{~g}+$ sugar $40 \mathrm{~g}+$ bacillus commercial (dilution 100 times) adding to sample until Moisture Content $60 \%+$ chicken manure and cow dung each $50 \mathrm{~g}$ C1 : SCG $150 \mathrm{~g}+$ sugar $40 \mathrm{~g}+$ bacillus commercial (dilution 100 times) adding to sample until Moisture Content $60 \%+$ chicken manure and cow dung each $100 \mathrm{~g}$ D1 : SCG $150 \mathrm{~g}+$ sugar $40 \mathrm{~g}+$ bacillus commercial (dilution 100 times) adding to sample until Moisture Content $60 \%+$ chicken manure and cow dung each $150 \mathrm{~g}$ A2, B2, C2, D2 : same composition with A1 until D1 but using activator fungi

A3, B3, C3, D3 : same composition with A1 until D1 but using activator Lactic Acid Bacteria.

Spent coffee grounds were fermented Robusta coffee from Jember, East Java, Indonesia. Then dried in oven laboratory at 60 degree Celsius. After, these materials were mixed and used in composting to achieve a mixture with $\mathrm{C} / \mathrm{N}$ ratio below 10 (for horticulture plant).

About 250 until $500 \mathrm{~g}$ dry material of each mixture was composted 56 days. The moisture was maintained in the range $45-60 \%$ of water content. The mixture was homogenized manually every day. The temperature was measured using a digital thermometer. Samples were taken on days $0,7,14,21,28,35$, and 56 .

\subsection{Physical and Chemical Analysis}

\subsubsection{Physical and Chemical Analysis of SCG}

Before composting is carried out screening of raw materials first, including analysis of hemicellulose, lignin. Analysis of hemicellulose and lignin, which is 30 $\mathrm{g}$ of coffee added acetic anhydrate $250 \mathrm{ml}$ and $1 \mathrm{M}$ $\mathrm{H}_{2} \mathrm{SO}_{4} 10 \mathrm{ml}$. then mixed and left for 1 week. Then it was heated 3 hours and added 2 molar $12 \mathrm{ml} \mathrm{NaOH}$. Cooled with tap water. Washed with a little acetic anhydrate. Then separated by vacuum between liquid and solid. Then add water and dry one night in an oven 60 degrees Celsius. Weighed the solids as cellulose and liquid as heated again using a vacuum, then weighed the weight as lignin.

In addition, screening of macro and micronutrient content related to their potential to be composted was also carried out.

\subsubsection{Physical and Chemical Analysis during Composting}

$\mathrm{pH}$ was determined by "Soil analysis" standard procedures ${ }^{15}$; the $\mathrm{C} / \mathrm{N}$ ratio were determined also in dry sample by Macro corder (JM 1000CN).

\section{Results and Discussion}

\subsection{Screening of Raw Material (SCG)}

The most important component of coffee beans is carbohydrate, as well as spent coffee grounds [12]. The SCGs used are coffee grounds from fermented coffee beans. As can be seen in Table 1, the content of hemicellulose and lignin from SCG were $37.28 \%$ and $22.45 \%$. These results same with the previous study of SCG [13]. A little difference with some of the results of other studies may difference the type of coffee, method of roasting and also brewing techniques. SCG also contains several minerals. As show in Table 2, Potassium $(3.72 \mathrm{mg} / \mathrm{g})$ is the most abundant element in coffee bean, followed by calcium $(1.38 \mathrm{mg} / \mathrm{g})$, magnesium $(1.11 \mathrm{mg} / \mathrm{g})$, phosphorus $(0.89 \mathrm{mg} / \mathrm{g})$ and sodium $(0.69 \mathrm{mg} / \mathrm{g})$. Usually, brewing cause most of the minerals elements are easily extracted [12], however SCG still contains potassium as dominant mineral.

Table 1. Chemical Content in SCG

\begin{tabular}{|l|c|}
\hline \multicolumn{1}{|c|}{ Chemical content } & Sample SCG (\%) \\
\hline 1. Hemiselulose & 37.28 \\
\hline 2. Lignin & 22.45 \\
\hline
\end{tabular}

Table 2. Mineral content in SCG

\begin{tabular}{|ll|c|}
\hline \multicolumn{2}{|l|}{ Mineral content } & Sample SCG $(\mathbf{m g} / \mathbf{g})$ \\
\hline 1. & $\mathrm{Ca}($ Calsium $)$ & 1.38 \\
\hline 2. & $\mathrm{K}$ (Pottasium) & 3.72 \\
\hline 3. & $\mathrm{Mg}$ (Magnesium) & 1.11 \\
\hline 4. & $\mathrm{Na}$ (Sodium) & 0.69 \\
\hline 5. & $\mathrm{P}$ (Phosphorus) & 0.89 \\
\hline
\end{tabular}

SCG also contains Carbon and Nitrogen ratios 1:19.5 (Tabel 3) which approaches the $\mathrm{C} / \mathrm{N}$ ratio of the soil, 1 : $\leqq 20$. Thus, SCG has the potential to be used as compost products because it has the macro and micronutrients needed by soil and plants.

Table 3. Macronutrient content of SCG

\begin{tabular}{|ll|c|}
\hline \multicolumn{2}{|l|}{ Macro nutrient content } & Sampel SCG (\%) \\
\hline 1. & Carbon & 46.24 \\
\hline 2. & Nitrogen & 2.37 \\
\hline $3 . \quad$ C/N ratio & $1: 19.51$ \\
\hline
\end{tabular}

\subsection{Physico-Chemical Characteristic of Compost SCG}

The maturity, stability, and quality of any compost can be assessed by determining changes in chemical and physical properties. The changes in physic-chemical characteristic of the mixtures during the composting process are explained below. 


\subsection{1. $\mathrm{pH}$}

As shown in Fig 5, the $\mathrm{pH}$ of all of the compost varied within days. However, starting from 56 days of composting period, the $\mathrm{pH}$ value was stabilized. [14] indicated, this is because of buffering nature of humic substances. For compost C1, D1, B2, C2, D2, B3, C3, $\mathrm{D} 3$ in general, the $\mathrm{pH}$ was found to decrease starting from the first week of composting, while the others was increase. The decrease in $\mathrm{pH}$ of decomposing organic materials might be due to the production of organic acids by microorganism, phenolic compounds and the further increase in $\mathrm{pH}$ might be due to the formation of ammonia during decomposition [15]. [5] also indicated that during the composting process, the decrease in the $\mathrm{pH}$ could be the phenomenon of the carbon dioxide emission in the composting pile, and the accumulation of organic acids. The relatively low $\mathrm{pH}$ of A2 may be due to the presence of acids in these materials, which is in agreement with the study of [15].

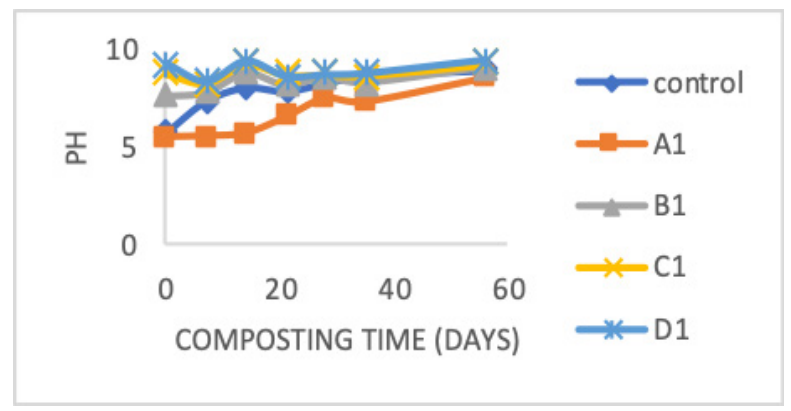

(a) $\mathrm{pH}$ Compost using Bacillus Commercial during Composting

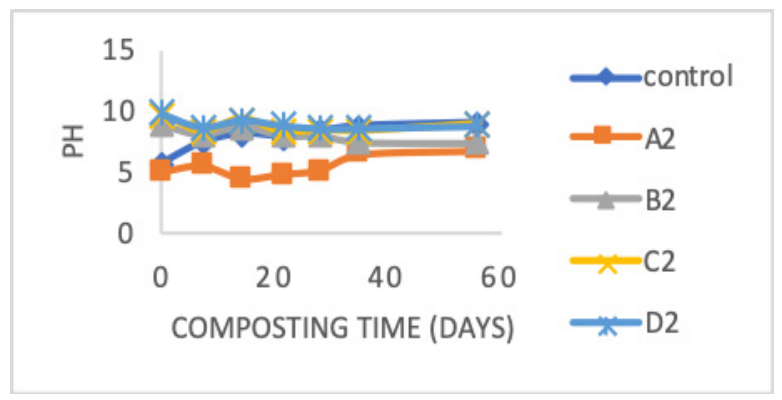

(b) pH Compost using Fungi during Composting

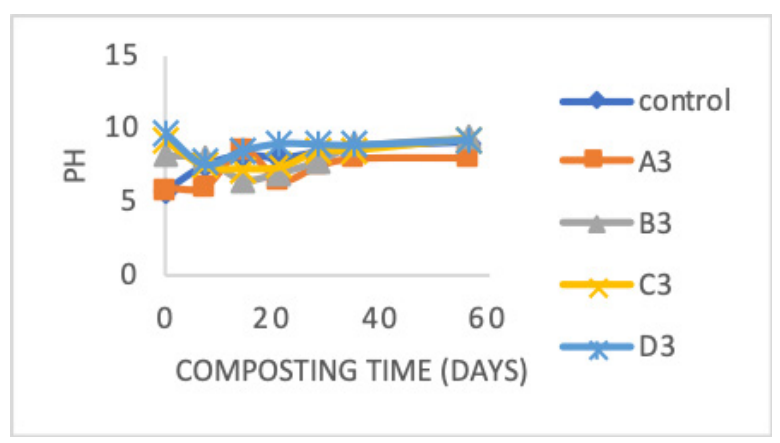

(c) $\mathrm{pH}$ Compost using $\mathrm{LAB}$ during Composting

Fig. 1. $\mathrm{pH}$ of Compost during Composting

Finally, for all compost types, the $\mathrm{pH}$ of matured compost samples was measured (6.42-8.86). This implies that the matured compost samples of this study are promising and can be used for the treatment acidic soils and do not need the addition of chemicals to adjust the $\mathrm{pH}$ before using it for soils. Only A2 have $\mathrm{pH}$ 6.42, whereas all sample slightly basic (7.6-8.86).

\subsection{2. $\mathrm{C} / \mathrm{N}$ ratio}

The $\mathrm{C} / \mathrm{N}$ ratio of all composting types varies with time. However, in general the $\mathrm{C} / \mathrm{N}$ ratio of all composting types was observed to decline with time, which indicates in Fig 2. Previous studies [16,17,18,19] also reported a decrement of $\mathrm{C} / \mathrm{N}$ values with time.

During the maturing phase as show of the composting process, the $\mathrm{C} / \mathrm{N}$ ratio of control, $\mathrm{C} 1$, and $\mathrm{A} 1$ (using Bacillus commercial) was found to be the lowest of all compost types. In general, during the maturing phase, the compost types A2 (using fungi activator) and A3 (using $\mathrm{LAB}$ activator) were found to have higher $\mathrm{C} / \mathrm{N}$ values than others. It is can be conclude that bacillus have decomposed activity better than fungi and LAB.

Thus, the $\mathrm{C} / \mathrm{N}$ for the final compost of all sample obtained in this study, which is in the range of 8.51-9.69, lies reasonably in the range which can be used for agricultural purposes. Thus, all the produced compost samples can be used for agricultural purposes.

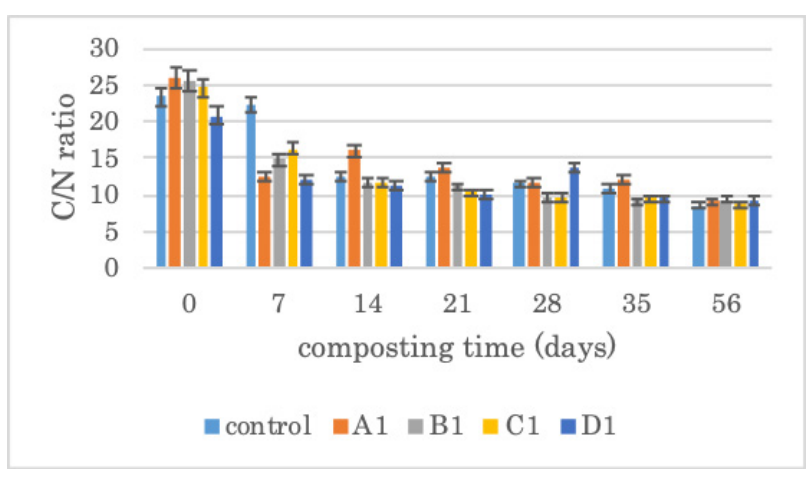

(a) $\mathrm{C} / \mathrm{N}$ ratio of compost using Bacillus commercial

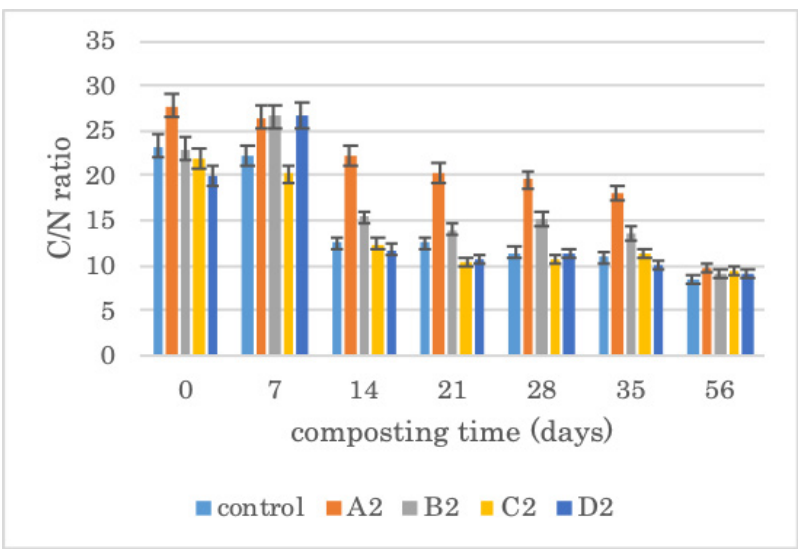

(b) $\mathrm{C} / \mathrm{N}$ ratio of compost using fungi activator 


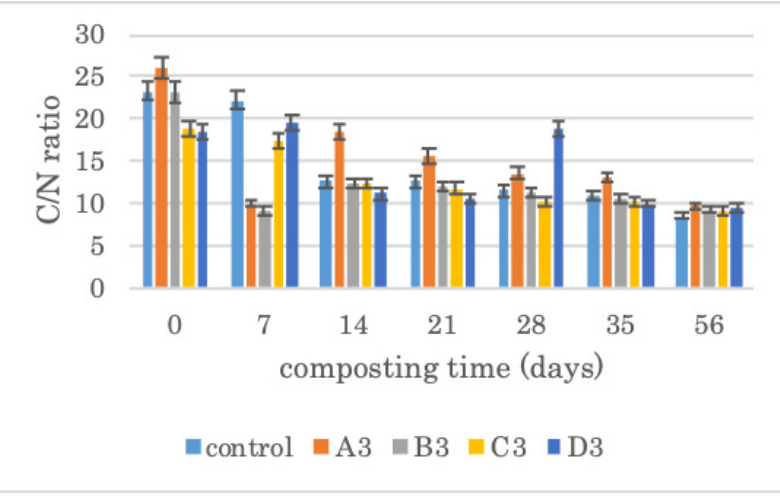

(c) $\mathrm{C} / \mathrm{N}$ ratio of compost using LAB Activator

Fig. 2. $\mathrm{C} / \mathrm{N}$ ratio during composting

\section{Conclusion}

Composting using bacillus produces a smaller $\mathrm{C} / \mathrm{N}$ ratio fungi and LAB (8.51/1). Bacillus has ability to degrade better than fungi and $\mathrm{LAB}$ in this study. However, these three types of activators are able to produce better compost characteristics than controls, with a composition of $\mathrm{C} / \mathrm{N}$ ratio that is not much different, 8-9/1 and $\mathrm{pH}$ which tends to be slightly alkaline (7.46-8.86).

\section{Acknowledgment}

I am deeply indebted to my supervisor, Professor Hiroyuki Harada for warm support, inspiration and thoughtful guidance. Also, I would like to thank to Islamic Development Bank for financial funding this research.

\section{References}

1. S.M. Tiqua, T.L. Richard, M.S. Honeyman, Carbon, nutrient, and mass loss during composting. Nutr. Cycl. Agroecosys. 62, 15-24 (2002).

2. T.A. Buttler, L.J. Sikora, L.W. Douglas. Compost age and sample storage effects on maturity indicators of biosolids compost. J. Environ. Qual. 30 (6), 2141-2148 (2001).

3. M. Ros, J.A. Pascual, C. Garcia. Hydrolase activities, microbial biomass and bacterial community in a soil after long termamendment with different composts. Soil Biol. Biochem. 38 (12), 3443-3452 (2006).

4. K.E. Lasaridi, E.I. Stentiford.. A simple respirometric technique for assesing compost stability. Water Res. 32 (12), 3717-3723 (1998).

5. B. Irawan. Preparation of Fungal Inoculum for Leaf Litter Composting from Selected Fungi. ARPN Journal of Agricultural and Biological Science 9 (3), 89-95 (2014).

6. N.D. Diallo. Composting of sugar cane bagasse by bacillus strains. African journal of biotechnology. 16 (3), 113-123 (2017).

7. R. Rebollido. Martinez J. Microbial population during composting process of organic fraction of municipal solid waste (2008).
8. J. Ryckeboer, J. Mergaert, J. Coosemans, K. Deprins, J. Swings. Microbiological aspects of biowaste during composting in a monitored compost bin. J. Appl. Microbiol. 94:127-137 (2003).

9. N.D. Diallo. Composting of sugar cane bagasse by bacillus strains. African journal of biotechnology. 16 (3), 113-123 (2017).

10. L.F. Ballesteros, J.A. Teixeira, S.I. Mussatto. Chemical, Functional, and Structural Properties of Spent Coffee Grounds and Coffee Silverskin. Food Bioprocess Technol, 3493-3503 (2014).

11. S. Gaind, L. Nain, V.B Patel. Quality Evaluation of Co-Composted Wheat Straw, Poultry Droppings and Oil Seed Cakes. Biodegradation. 20: 307-317 (2009).

12. Arya, Rao. An impression of Coffee Carbohydrate. Critical review in food science and nutrition, 47:5167 (2007).

13. S.I. Mussatto, E.M.S. Machado, S. Martins, J.A. Teixeira,. Production, composition, and application of coffee and its industrial residues. Food Bioprocess Technol. 4, 661-672, (2011b).

14. S. Catia, A. Aires, J. fonseca, J. Cotinho. Effect of different rates of spent coffee ground (SCG) on composting process, gasseous emission and quality of end product. J. Waste Management. 59, 37-47 (2016).

15. D. Preethu, Bhanu, B. Prakash, C. Srinivasamurthy, B. Vasanthi. Maturity indices as an index to evaluate the quality of compost of coffee waste blended with other organic wastes. In: Proceeding of international conference on sustainable solid waste management, Chennai, India, Citeseer, pp 270-275 (2007)

16. K. Liu, G. Price. Evaluation of three composting systems for the management of spent coffee grounds. Bioresour Technol 102:7966-7974 (2011).

17. D. Dadi, H. Sulaiman, S. Leta. Evaluation of composting and the quality of compost from the source separated municipal solid waste. J Appl Sci Environ Manag 16:5-10 (2012).

18. T. Getahun, E. Mengistie, A. Haddis, F. Wasie, Alemayehu E, Dadi D, Van Gerven T, Van der Bruggen B. Municipal solid waste generation in growing urban areas in Africa: current practices and relation to socioeconomic factors in Jimma, Ethiopia. Environ Monit Assess 184:6337-6345 (2012a).

19. F. Shemekite, M.G Brandón, I.H.F. Whittle, B. Praehauser, H. Insam, F. Assefa. Coffee husk composting: an investigation of the process using molecular and non-molecular tools. Waste Management 34:642-652 (2014 